\title{
Superinfection Exclusion in Mosquitoes and Its Potential as an Arbovirus Control Strategy
}

\author{
Mathilde Laureti 1,2,*, Prasad N. Paradkar ${ }^{2} \mathbb{D}$, John K. Fazakerley $^{1}(\mathbb{D})$ and \\ Julio Rodriguez-Andres 1,*(D) \\ 1 Peter Doherty Institute for Infection and Immunity and Faculty of Veterinary and Agricultural Sciences, \\ University of Melbourne, VIC 3000 Melbourne, Australia; john.fazakerley@unimelb.edu.au \\ 2 CSIRO Health \& Biosecurity, Australian Centre for Diseases Preparedness, VIC 3220 Geelong, Australia; \\ Prasad.Paradkar@csiro.au \\ * Correspondence: mlaureti@student.unimelb.edu.au (M.L.); julio.rodriguez@unimelb.edu.au (J.R.-A.)
}

Received: 29 September 2020; Accepted: 28 October 2020; Published: 5 November 2020

\begin{abstract}
The continuing emergence of arbovirus disease outbreaks around the world, despite the use of vector control strategies, warrants the development of new strategies to reduce arbovirus transmission. Superinfection exclusion, a phenomenon whereby a primary virus infection prevents the replication of a second closely related virus, has potential to control arbovirus disease emergence and outbreaks. This phenomenon has been observed for many years in plants, insects and mammalian cells. In this review, we discuss the significance of identifying novel vector control strategies, summarize studies exploring arbovirus superinfection exclusion and consider the potential for this phenomenon to be the basis for novel arbovirus control strategies.
\end{abstract}

Keywords: superinfection exclusion; arbovirus; vector control

\section{Introduction}

Over the past century, there has been continual emergence and re-emergence of arbovirus diseases, with more than $80 \%$ of the world's population at risk of infection [1]. Arboviruses (Arthropod-Borne viruses) include mosquito-borne viruses, such as yellow fever (YFV), Zika (ZIKV), West Nile (WNV), Japanese encephalitis (JEV), dengue (DENV) and chikungunya (CHIKV) viruses, and tick-borne viruses such as tick-borne encephalitis virus (TBEV) [2]. Globally, there are over 100 arbovirus diseases of human and veterinary health concern [3]. The epizootic transmission and pandemic potential of arboviruses are affected by several factors including climate change, population growth, urbanization and intercontinental travel and trade [2,4]. For example, both global warming and human travel and trade are expanding the range of viral vectors like the Aedes spp. mosquitoes [5]. Several strategies are being used and developed to counter the spread of these viruses by mosquitoes. These include the use of pesticides, infection with the bacterium Wolbachia and the use of genetically modified mosquitoes. In this review, we will discuss superinfection exclusion as an alternative strategy. This strategy is based on the premises that if a mosquito is infected with a non-pathogenic virus, a secondary infection with a related pathogenic virus is less likely, reducing or preventing the transmission of the second infection.

\section{Arboviruses}

Arboviruses are found across several virus groups including the single-stranded, positive-sense RNA viruses of the Flaviviridae and Togaviridae, the segmented negative-sense RNA Bunyaviridae and the segmented double-stranded (ds)RNA viruses of the Reoviridae.

The Flaviviridae family contains over 70 arboviruses including some of the most medically important ZIKV, DENV, JEV, WNV and YFV [6]. They include both mosquito-borne and tick-borne 
viruses [7,8]. More than 40 flaviviruses have been associated with human disease, and the number is expected to grow [2]. Some flaviviruses have more than one serotype, increasing the number of known human pathogens. For example, there are four major antigenically distinct DENV serotypes, DENV-1-4, with a fifth of them under investigation $[9,10]$. In 2012, at least one of the four DENV serotypes was reported in over 120 countries, placing approximately $50 \%$ of the world's population at risk [11]. After causing global outbreaks, ZIKV is currently circulating in more than 87 countries around the world according to WHO's latest epidemiological update. However, ZIKV infection remains asymptomatic in $80 \%$ of cases, with rare severe clinical outcomes such as microcephaly and Guillain-Barré syndrome [12]. JEV, one of the major causes of viral meningoencephalitis in the world, has been reported in at least 24 countries, endangering more than 3 million people, and YFV is still detected in 40 countries despite the availability of an effective vaccine since the 1930s $[13,14]$.

The Alphavirus genus within the Togaviridae family is generally divided into groups based on clinical symptoms. The arthritogenic viruses include CHIKV, Sindbis (SINV) and Ross River (RRV) viruses. The encephalitic viruses include Eastern equine encephalitis (EEEV), Venezuelan equine encephalitis (VEEV), and Western equine encephalitis (WEEV) viruses. Phylogenetically, the Alphavirus genus includes an aquatic virus clade encompassing salmon pancreas disease virus and sleeping disease virus, a Sindbis clade (SINV), an equine encephalitis clade (VEEV, EEV and WEEV) and a Semliki Forest clade (SFV, RRV, CHIKV) [15]. CHIKV infection is normally not life-threatening but is responsible for high morbidity with painful and long-term symptoms, such as crippling arthralgia that may require hospitalization, but it can cause fatal encephalopathy, encephalitis and multiple-organ failure [16]. The virus is endemic in Africa where it is vectored by Aedes aegypti. A single amino acid change in the viral envelope E1 protein allowed its adaptation to Aedes albopictus, leading to the global expansion of CHIKV, with far-reaching consequences [17]. From 2005 to 2006, more than 1.5 million cases were reported in the Indian Ocean, with subsequent spread in 2007 to Italy and France [4,18]. During the epidemic on La Reunion Island, one-third of the island population was infected by CHIKV and hospitalized within six months, at a medical cost of $€ 44$ million [19]. In 2013-2016, there were outbreaks in the Caribbean and Brazil [20]. In 2016, CHIKV was responsible for more than 1 million infections in the Americas [21]. SINV is the alphavirus with the widest global distribution and can be found on most continents [22]. SINV strains isolated in Europe have been linked to Pogosta disease in Finland, Ockelbo disease in Sweden and Karelian fever in Russia, three clinically similar diseases characterized by polyarthritis, myalgia, headache, low fever and rash [23-25]. RRV is another arthritogenic alphavirus transmitted by both Aedes and Culex mosquitoes. It is endemic to Australia, with approximately 5000 new cases per annum [26]. Outbreaks have also been recorded in Fiji, New Caledonia, Samoa and the Cook Islands with tens of thousands of infections [27-29].

Since many of these flaviviruses and alphaviruses are transmitted by the same mosquito vectors, overlapping outbreaks of these viruses have been recorded. For example, during 2016-2017, overlapping outbreaks of CHIK, DENV and ZIKV were reported in 36 countries, associated with Ae. aegypti transmission [30]. Newly emerging arboviruses including Mayaro virus [31], African swine fever virus [32] and new strains of bluetongue and Usutu viruses [33] represent threats to human and animal health [34]. With the exception of YFV, DENV and JEV, there are no approved vaccines available for human clinical use for arboviruses, and vector control remains an important strategy to prevent these diseases.

\subsection{Insect-Specific Viruses}

Insect-specific viruses (ISVs), i.e., viruses that replicate solely in insects, have been found so far in both the Flaviviridae and the Togaviridae families. These viruses cannot infect vertebrates and therefore are not zoonotic. Over the last decade, with the increasing use of high-throughput sequencing driving virus discovery, increasing numbers of ISVs have been discovered in mosquitoes [35].

The first discovered insect-specific flavivirus (ISFV), i.e., cell-fusing agent virus, was found in Ae. aegypti mosquito cell lines and named after the syncytia it forms in these cells [36]. In 2003, 
another ISFV, the Kamiti River virus, was isolated from Aedes mcintoshi mosquitoes in central Kenya [37]. In 2007, a Culex-specific flavivirus was isolated from mosquitoes in Japan [38]. More sequence-related ISFVs have since been discovered around the world: Aedes-specific flaviviruses in Japan, Italy and the USA, Nakiwogo virus in Uganda, Calbertado virus in Colorado (USA), Quang Binh virus in Vietnam, Hanko virus in Finland, Palm Creek virus in Australia and many more [39-46]. ISFVs are phylogenetically classified in two groups [47]. One of those groups is clearly distinct from any other known flavivirus and includes cell-fusing agent virus, Kamiti River virus and Culex flavivirus. The second group is related to vertebrate flaviviruses and includes Chaoyang virus, Nounané virus and Lammi viruses. Molecular phylogeny studies estimate that there may be in the order of 2000 ISFVs to be discovered [48].

Unlike ISFVs, only a few insect-specific alphaviruses (ISAV) have been discovered so far: Eilat virus (EILV), Taï Forest alphavirus (TAFV), Mwinilunga virus (MWAV), Agua Salud virus (ASALV) and Yada Yada virus (YYV) [49-53]. TAFV was discovered in the Taï national park in the Ivory Coast in Culex decens mosquitoes [49]. MWAV was isolated from a pool of Culex quinquefasciatus mosquitoes from Zambia [50]. ASALV and YYV are the most recently discovered ISAVs. ASALV was isolated from a pool of Culex mosquitoes in Central Panama, and YYV was isolated from Anopheles annulipes mosquitoes in Australia [51,53]. EILV, the first ISAV described, was isolated from a pool of Anopheles coustani mosquitoes collected near Jerusalem in 1984 [54]. EILV does not infect mammalian cells or mouse brain, a tissue which has been historically used to amplify or isolate many viruses [52]. Aedes, Anopheles and Culex mosquitoes are susceptible to EILV infection. However, Ae. albopictus seems to be refractory to oral infection, while Ae. aegypti is susceptible to both oral and intrathoracic infection [55].

Insect-specific viruses seem to have potential as an arbovirus control method in several ways, from making mosquitoes refractory to related arboviruses to reducing mosquito fitness and fertility [56,57]. However, more research about their transmission and specificity is necessary to their enable large-scale implementation [58].

\subsection{Current Control Stategies}

The main vector control strategies for arboviruses include larvicides, insecticides, suppression of breeding sites, bed nets and insect repellents. Each of these has limitations. Mosquitoes such as Ae. aegypti can breed in a small volume of water, and suppression of every breeding site is unrealistic. Ae. aegypti and Ae. albopictus are day biters, so bed nets have little efficacy. Mosquito resistance to insecticides is increasing worldwide, and with high costs and environmental damage, its usage is unsustainable, in addition to the lack of evidence of the effect of pesticides on areas with outbreaks [59]. New control strategies are needed to control mosquito-borne diseases.

\subsection{Novel Control Strategies}

Several new vector control strategies are under investigation. The environmentally friendly, naturally occurring symbiotic Wolbachia bacteria found in many insects have emerged as a new effective vector control mechanism. Mating of Wolbachia-infected male mosquitoes with uninfected wild female mosquitoes leads to sterile eggs and population suppression, whereas mating between Wolbachia-infected female mosquitoes and infected or uninfected male mosquitoes gives rise to fertile eggs and offspring [60,61]. Through this mechanism, Wolbachia infection is driven into a mosquito population. So far, 18 supergroups of Wolbachia have been discovered in the wild [62]. There are now multiple studies showing that Wolbachia infection of female mosquitoes prevents the transmission of DENV and CHIKV [61,63-69]. Field studies are underway to determine whether driving Wolbachia into mosquito populations in areas endemic for DENV can reduce the incidence of dengue fever; results to date are promising [66-68,70-73]. Further studies are required to fully understand the mechanism by which Wolbachia prevents arbovirus transmission and to understand the ecological effects of introducing this bacterium into wild Ae. aegypti mosquito populations, which are not naturally 
infected [59]. There is also concern that Wolbachia infection of mosquitoes might drive the evolution of viruses with increased infectivity or virulence [74].

Other novel systems to control arbovirus transmission involve the genetic modification (GM) of mosquitoes [75]. The sterile insect technique has previously been used for decades to prevent the transfer of new-world screwworm blowflies from south to north America [76]. Large numbers of insects are bred, radiation-sterilized and released. Wild females mated with sterile males lay no eggs, resulting in a crash in the blowfly population. Studies are underway to replace irradiation with genetically modified conditionally sterile males [77]. Other GM approaches include creating mosquitoes carrying a genetic payload system which can be transmitted to the female progeny, which renders these female mosquitoes resistant to a specific arbovirus infection [78]. Manipulating mosquito immunity to induce death upon infection can be argued to be more effective than resistance to infection, since the former is less likely to drive virus evolution [79]. These technologies rely on recent advances in mosquito genetics as well as on CRISPR-Cas9 technology [80]. The ability to drive genetic change into a population while ensuring it does no lasting ecological damage is a challenge. GM mosquitoes are currently being developed and studied in laboratories around the world. GM mosquito technology is relatively new, but as with Wolbachia, field trials are currently underway. In 2016, billions of GE OX513A Ae. aegypti mosquitoes were released in areas of Brazil with a high incidence of DENV and ZIKV cases. Ae. aegypti OX513A is a genetically engineered strain carrying a self-limiting gene which renders mating between OX513A males and wild-type females unproductive [81]. Initial studies from Grand Cayman, Brazil and Panama have reported significant reductions in vector abundance. Ae. aegypti OX5034 are male-selective, and mating between OX5034 and wild-type females results in the survival of only the male progeny [82]. The release of OX5034 has recently been approved for use in Florida to reduce the incidence of dengue [81-83]. The use of both Wolbachia and GM mosquitoes requires extensive regulation and public engagement, but both technologies have good potential to control arbovirus outbreaks [84].

\section{Superinfection Exclusion}

Superinfection exclusion is observed when a first infection prevents the replication of a second infection by a genetically identical or a genetically closely related virus; this phenomenon is also termed homologous and heterologous interference, respectively. Superinfection exclusion could be another arbovirus control strategy.

Interference between plant viruses has been recognized and studied for almost a century [85-87]. Cross-protective interference has been developed in agriculture and horticulture to protect plants from pathogenic viruses by deliberate prior infection with an attenuated strain of the same virus [88]. Recent decades have witnessed enormous progress in understanding plant immunity, which principally works through the recognition of pathogen-associated molecular patterns (PAMPs) by pattern recognition receptors (PRR) on the cell surface and within the cell $[89,90]$. dsRNA is a PAMP associated with RNA virus infections. Cellular RNA is single-stranded, but viruses with an RNA genome must replicate their RNA and, in doing so, they form dsRNA. The RNA interference (RNAi) plant immunity system detects and destroys the viral RNA. Virus dsRNA is detected by the PRR dicer-like protein (DCL). This cleaves the virus dsRNA into small RNAs, one strand of which is then incorporated into an RNA-induced silencing complex (RISC). This in turn silences, that is, degrades, sequence-complementary RNA [91]. While plant immunity, and RNAi in particular, may explain the described interference between many plant viruses, which has in some cases been termed superinfection exclusion, there is evidence that other mechanisms, related not to host systems but to properties of the virus, may also be at work [87].

In mammals, the innate and adaptative immune systems provide protection against sequential infections between distantly and closely related viruses. In mammalian cell culture, as in plants, the term superinfection exclusion has been used over many decades to denote the phenomenon by which one virus infection precludes the replication of a second infection by a related virus [92-94]. 
The powerful antiviral interferon system, a component of innate immunity in mammals, provides highly effective cross-protection between even unrelated viruses, at least for a short period after primary infection [95]. While some cases termed superinfection exclusion in mammalian cells can probably be attributed to interferons or other aspects of innate immunity, other mechanisms of exclusion also appear to be operating [96-98].

In arthropods, virus co-infection and superinfection exclusion have been studied in mosquitoes and mosquito cells for many years [99] (Table 1). Both homologous and heterologous interference are observed in Aedes mosquito cells persistently infected with SINV [100]. That is, once infected with SINV, the cells cannot be superinfected with other strains of SINV or other alphaviruses [100-102]. However, these same cells can be superinfected with unrelated bunyaviruses or the flavivirus YFV [102]. Heterologous interference is also observed in insect cells infected with flaviviruses, for example with YFV- in DENV-2-infected Ae. albopictus cells [99]. In mosquitoes, several studies have demonstrated that sequential infection by viruses of different families results in coinfection, not in exclusion [103-105]. 
Table 1. List of published papers reporting superinfection exclusion and co-infection phenomena in Aedes mosquito cells and Aedes mosquitoes [46,99-104,106-110]. Viruses: SINV, Sindbis, CHIV; chikungunya, DENV, dengue, SFV; RVV; Ross River, PCV, MVEV, WNV, West Nile, NHUV, SLEV, St. Louis encephalitis, JEV, Japanese encephalitis, VEEV, Venezuelan equine encephalitis, EEV, Eastern equine encephalitis, YFV, yellow fever, ZIKV, Zika.

\begin{tabular}{|c|c|c|c|c|c|}
\hline $\begin{array}{l}\text { Primary Infecting } \\
\text { Virus (Family) }\end{array}$ & Observed Superinfection Exclusion & No Superinfection Exclusion & Cell Line & Mosquito Species & References \\
\hline SINV (Alphaviridae) & SINV (Alphaviridae) & EEEV (Alphaviridae) & Aedes albopictus & & [100] \\
\hline SINV (Alphaviridae) & $\begin{array}{c}\text { SINV (Alphaviridae) } \\
\text { SFV (Alphaviridae) } \\
\text { Una virus (Alphaviridae) } \\
\text { CHIKV (Alphaviridae) }\end{array}$ & $\begin{array}{l}\text { Snowshoe hare virus } \\
\text { (Peribunyaviridae) }\end{array}$ & Ae. albopictus & & [101] \\
\hline $\begin{array}{c}\text { La Crosse virus } \\
\text { (Peribunyaviridae) }\end{array}$ & Snowshoe hare virus (Peribunyaviridae) & & & Aedes triseriatus & \multirow{2}{*}{ [106] } \\
\hline $\begin{array}{l}\text { Snowshoe hare virus } \\
\text { (Peribunyaviridae) }\end{array}$ & La Crosse virus (Peribunyaviridae) & & & Ae. triseriatus & \\
\hline SINV (Alphaviridae) & $\begin{array}{c}\text { Aura virus (Alphaviridae) } \\
\text { SFV (Alphaviridae) } \\
\text { RRV (Alphaviridae) }\end{array}$ & YFV (Flaviviridae) & $\begin{array}{c}\text { C6/36, C7-10 and U4.4 } \\
\text { (Ae. albopictus) }\end{array}$ & & [102] \\
\hline DENV-1 (Flaviviridae) & & CHIKV (Alphaviridae) & & Ae. albopictus & [103] \\
\hline PCV (Flaviviridae) & $\begin{array}{l}\text { MVEV (Flaviviridae) } \\
\text { WNV (Flaviviridae) }\end{array}$ & & $\begin{array}{c}\text { C6/36 } \\
\text { (Ae. albopictus) }\end{array}$ & & [46] \\
\hline NHUV (Flaviviridae) & $\begin{array}{l}\text { WNV (Flaviviridae) } \\
\text { JEV (Flaviviridae) } \\
\text { SLEV (Flaviviridae) }\end{array}$ & & $\begin{array}{c}\mathrm{C} 6 / 36 \\
\text { (Ae. albopictus) }\end{array}$ & & [107] \\
\hline EILV (Alphaviridae) & $\begin{array}{l}\text { SINV (Alphaviridae) } \\
\text { VEEV (Alphaviridae) } \\
\text { EEEV (Alphaviridae) }\end{array}$ & CHIKV (Alphaviridae) & $\begin{array}{c}17 / 10 \\
\text { (Ae. albopictus) }\end{array}$ & Aedes aegupti & [108] \\
\hline NHUV (Flaviviridae) & WNV (Flaviviridae) & & $\begin{array}{c}\mathrm{C} 6 / 36 \\
\text { (Ae. albopictus) }\end{array}$ & & [109] \\
\hline
\end{tabular}


Table 1. Cont

\begin{tabular}{|c|c|c|c|c|c|}
\hline $\begin{array}{l}\text { Primary Infecting Virus } \\
\text { (Family) }\end{array}$ & Observed Superinfection Exclusion & No Superinfection Exclusion & Cell Line & Mosquito Species & References \\
\hline DENV-2 (Flaviviridae) & DENV-2 (Flaviviridae) & \multirow{3}{*}{\multicolumn{2}{|c|}{$\begin{array}{c}\mathrm{C} 6 / 36 \\
\text { (Ae. albopictus) }\end{array}$}} & & \multirow{3}{*}{ [99] } \\
\hline DLit) & YFV (Flaviviridae) & & & & \\
\hline YFV (Flaviviridae) & $\begin{array}{l}\text { DENV-2 (Flaviviridae) } \\
\text { YFV (Flaviviridae) }\end{array}$ & & & & \\
\hline ZIKV (Flaviviridae) & & CHIKV (Alphaviridae) & $\begin{array}{c}\mathrm{C} 6 / 36 \\
\text { (Ae. albopictus) }\end{array}$ & Ae. aegypti & [104] \\
\hline NHUV (Flaviviridae) & $\begin{array}{c}\text { ZIKV (Flaviviridae) } \\
\text { DENV-2 (Flaviviridae) }\end{array}$ & CHIKV (Alphaviridae) & $\begin{array}{c}\mathrm{C} 6 / 36 \\
\text { (Ae. albopictus) }\end{array}$ & & [110] \\
\hline
\end{tabular}




\section{Mechanisms of Superinfection Exclusion}

From the point of view of virus evolution, superinfection exclusion could be considered a selective advantage mediated by a virus-encoded mechanism that functions to reduce competition for limited cellular resources by preventing entry into the cell, or replication within the cell, of additional viruses [111]. This phenomenon is mostly observed between closely related viruses, suggesting that competition for resources, interference between virus-derived molecules or activation of specific cellular defenses may play important roles in this event [112]. Interestingly, however, there are cases when interference might occur between different viral families. Menghai rhabdovirus (MERV) and Shinobi tetravirus (SHTV) infection of Ae. Albopictus-derived C6/36 cells suppressed superinfected ZIKV growth [113]. In addition, the opposite can also occur with unrelated viruses, for example the Ae. aegypti totivirus (AaTV) from the Totiviridae family has shown to boost superinfecting DENV-1 production in C6/36 cells [114]. The mechanisms of this interaction remain unknown [111].

In mammalian cells, superinfection exclusion has been reported to occur at virus entry or upon virus replication [115-118]. Superinfection exclusion can be established rapidly after primary infection. Studies on SINV and SFV heterologous interference show that cellular DNA-dependent transcription is not required for superinfection exclusion to function, suggesting it is not interferon-mediated [92]. SFV infection of BHK-21 cells showed that 15 min of primary infection was sufficient to establish exclusion by a superinfecting virus and that the second virus was unable to bind to the pre-infected cells [119]. In Madin-Darby bovine kidney (MDBK) epithelial cells infected with the flavivirus bovine viral diarrhea virus (BVDV), superinfection exclusion was functional in less than an hour, consistent with a block at virus entry [117]. Competition for binding to cellular receptors and the decreased number of cell surface receptors available after primary infection could be the mechanism mediating interference for the second infection [119]. Given the specificity of receptor binding, this would be consistent with exclusion only between related viruses.

In the case of the two viruses considered above, bypassing virus cell surface receptors by transfecting virus RNA into pre-infected cells did not prevent exclusion by SINV in BHK-21 cells or by BVDV in MDBK cells $[117,118]$. In addition to interference with second virus entry, there are several potential points in virus replication within the cell at which the products of a first infecting virus could interfere with the replication of a related second incoming virus. To consider this requires an understanding of virus replication; alphaviruses provide an example. Upon entry into the cytosol, alphavirus nucleocapsids bind to ribosomes. This triggers nucleocapsid disassembly and release of the virus genomic RNA [120]. This provides potential for a first virus to prevent infection of a second through saturation by the first virus of the capsid protein binding sites on ribosomes, preventing nucleocapsid binding and disassembly of a second virus infection [121]. However, in BHK-21 cells infected with SFV, superinfection exclusion still occurred when the primary infection was a recombinant virus that produced no capsid protein [119]. Upon release of the virus genome from the nucleocapsid, alphavirus replication starts with the translation of the non-structural polyprotein (ns) P1234 encoded at the $5^{\prime}$ end of the virus genomic RNA. A second open reading frame (ORF), translated from a subgenomic RNA, encodes for the structural polyprotein [122]. The alphavirus structural proteins are involved in viral assembly, release, transmission, attachment and entry. The components of the non-structural polyprotein mediate replication and transcription of the virus RNA. P1234 is processed into four mature non-structural proteins (nsP) 1-4. The functional proteins are separated by the activity of a protease located in nsP2. Processing leads to sequential release of nsP4 and nsP1 and then separation of nsP2 and nsP3. The extent of processing determines the substrate specificity of the replicase complex which switches from synthesis of negative-stranded genomic complementary RNA to synthesis of subgenomic and genomic RNA upon cleavage at the nsP2-nsP3 junction [123,124]. SFV nsP1 does not mediate superinfection exclusion, since cells expressing it do not block subsequent SFV entry or replication [125]. The nsP2 protease has been suggested to mediate superinfection exclusion on the basis that the replicase polyprotein synthesized from a new alphavirus genome entering a pre-infected cell could be rapidly processed by existing nsP2 protease. The fully processed 
replicase produces genomic RNA from a genome complementary negative-sense RNA substrate. The rapid processing of the new replicase polyprotein could result in no negative-stranded template and thus no genome replication of the second virus [102]. Attempts to investigate this by expressing nsP2 have been unsuccessful, as this virus protein, expressed in the absence of the other replicase proteins, is toxic to mammalian cells [126]. For the flavivirus WNV, a mutation in the non-structural protein NS4A of WNV-infected BHK-21 cells allowed superinfecting wild-type WNV to overcome exclusion [127].

In arthropods, as in plants, dsRNA formed by RNA virus replication in the cytoplasm activates the cellular RNAi defense system, which generates specific immunity that degrades RNAs containing identical sequences. The system consists of a number of related pathways; 21 nucleotide sequence identities form the basis of the siRNA pathway, while larger nucleotide identities of up to 30 nucleotides form the basis of the piRNA pathway. For RNAi to be cross-protective between viruses, therefore, regions of RNA sequence identity from 21 to 30 nucleotides are required. Alignment of the $11 \mathrm{~kb}$ alphavirus genomes of CHIKV and SINV demonstrates no 21-30 nucleotides sequence identities. Ae. albopictus $\mathrm{C} 6 / 36$ and $\mathrm{C} 7 / 10$ cells lack a functional dicer-2 protein and siRNA pathway but have a functional piRNA pathway [128,129]. Upon virus infection, these cells demonstrate no 21nt siRNA response and a delayed piRNA response but remain efficient at superinfection exclusion, suggesting that the siRNA pathway is not required but not ruling out its contribution [102,130].

The alphavirus genome encodes five structural proteins: the capsid, the envelope proteins E1, E2 and E3, as well as the 6K envelope protein [131]. The structural polyprotein is cleaved into these functional proteins by viral and cellular proteases [132]. The capsid is cleaved first, leaving the polyprotein precursor E3-E2-6K-E1 which is processed by the cellular signalase protease into $6 \mathrm{~K}$, E3E2 (PE2) and E1 [133]. E2 is responsible for receptor-mediated endocytosis, while E1 mediates fusion of the viral membrane with that of the endolysosome [134,135]. The 6K protein has a transmembrane domain involved in ion-channel activity and another transmembrane domain which interacts with E1 [131]. In SFV-infected BHK-21 cells, virus inability to produce capsid protein did not prevent superinfection exclusion [119]. For WNV, the absence of structural proteins (C, M and Env) did not significantly affect heterologous interference with the related flaviviruses YFV or DENV-2; however, St. Louis encephalitis virus (SLEV) titers were severely hindered by the expression of the WNV nonstructural replicon alone [136]. In contrast, in MDBK cells harboring recombinant BVDV with deletions of E2, E1, or C proteins, deletion of E2, but not of E1 or C, abolished subsequent superinfection exclusion [117]. The BVDV E2 protein is essential for the generation of new infectious virions, but how the E2 protein mediates superinfection exclusion remains unclear [117,137].

\section{Superinfection Exclusion as an Arbovirus Control Strategy}

The persistent emergence and re-emergence of mosquito-transmitted viral diseases, such as chikungunya, dengue and Zika, warrants new arbovirus control strategies. As with yellow fever, vaccination is likely to be powerful and important. Dengue vaccines have been recently approved, and chikungunya and new Japanese encephalitis vaccines are under development. In the control of mosquito transmission, Wolbachia infection and genetically modified mosquitoes show promise. The relatively recent discovery of insect-only alphaviruses and flaviviruses suggests that, as for Wolbachia infection, an insect-only arbovirus might effectively preclude infection with, or transmission of, a related zoonotic arbovirus.

Many zoonotic arboviruses share mosquito vector species, and spatially and temporally overlapping outbreaks of arbovirus disease are well documented [30]. For example, in recent decades, many of the outbreaks of chikungunya and Zika have occurred in areas with a high ongoing incidence of dengue. Reports that mosquitoes can be naturally infected with more than one arbovirus include Ae. aegypti co-infection with ZIKV and CHIKV and with ZIKV, CHIKV and DENV, and Ae. albopictus co-infection with DENV and CHIKV $[103,104,138]$. Co-infections have also been observed in artificially fed Ae. aegypti with DENV and CHIKV as well as triple infection with CHIKV, DENV and ZIKV [138]. 
In contrast to these co-infections with genetically unrelated or distantly related viruses, Ae. aegypti infected with one DENV serotype have decreased susceptibility to infection with other serotypes [110]. In another study of Ae. Aegypti experimentally infected with DENV and ZIKV, the mosquitoes became co-infected, but only ZIKV was present in saliva [139]. In a rare insight into what may be happening in ticks, in a screening for virus infection of Ixodes scapularis ticks, no co-occurrence was observed between two different strains of Blacklegged tick phlebovirus, suggesting exclusion between these viruses [140].

There is evidence that insect-only arboviruses can prevent infection or transmission of a related zoonotic arbovirus. Studies on the mosquito-specific alphavirus EILV demonstrated both homologous and heterologous interference in Ae. albopictus cells [52]. EILV infection blocks superinfection of a different strain of EILV or different alphaviruses including SINV, VEEV, EEV, WEEV and CHIKV [108]. This same study also investigated heterologous interference in Ae. Aegypti, a mosquito susceptible to both EILV and CHIKV infection. Mosquitoes were intra-thoracically injected with EILV and blood-fed 7 days later with CHIKV. Absolute exclusion was not observed, but there was a 3-day delay in CHIKV dissemination in the mosquitoes [108]. In Ae aegypti, ZIKV transmission could be blocked by prior infection with an insect-specific flavivirus [141].

In mosquitoes, it is unlikely that all cells will be infected with a first virus, leading to uninfected cells being available to be infected by a second virus. However, the situation in culture is very different, since superinfection exclusion requires a cell to be infected with a first virus before it can exclude a second one. Because of the high multiplicity of infection in vitro, most cells may be infected with a first virus, leading to effective exclusion of a second virus. The situation in vivo may be different if the mechanism of superinfection exclusion function without all cells needing to be infected by the first virus. In mosquitoes, as in plants, there is evidence that the RNAi defense system may be transmitted from infected cells to uninfected cells, with the potential to protect the whole organism [142]. Mosquitoes genetically modifying to express RNAi-activating sequences from pathogenic or insect-only viruses offer a possibility, enhanced by the finding that infection of insects with RNA viruses results in reverse transcription to DNA in a system that amplifies the RNAi response and provides both specificity and memory [143,144].

Understanding and characterizing the mechanisms behind superinfection exclusion is key in utilizing this phenomenon for controlling arboviruses. The use of superinfection exclusion as an arbovirus control strategy could, in theory, be viable but it presents several challenges. The mechanism by which one virus blocks another in a specific vector is quite complex. Superinfection exclusion seems very specific/restricted to mostly some viruses within the same family. There are several regulatory hurdles to be considered before implementing such strategy. Mosquitoes infected with low-pathogenicity arboviruses can still infect vertebrate hosts and, in some cases, they might cause mild disease. Insect-specific viruses could prove valuable here, but their transmission rates and their effect on mosquito fitness will need to be investigated. More detailed studies into the mechanisms of refraction between related viruses are needed.

Once these challenges are overcome, it could be plausible to infect local populations of mosquitoes with non-pathogenic viruses or with insect-specific viruses to reduce the prevalence of a pathogenic virus. The strategies for carrying this out are already being used for Wolbachia population replacement programs. This method would maintain local mosquito populations and the environment intact, without the need of pesticides or genetic manipulation. In addition, understanding the mechanisms of superinfection exclusion could allow us to develop new genetically engineered mosquitoes with lower fitness cost. This understudied research area is challenging but will provide a novel alternative to reduce the impact of arboviruses.

Author Contributions: Conceptualization, M.L. and J.R.-A. Writing-Original draft preparation, M.L. Writing-Review and editing, J.K.F., P.N.P. and J.R.-A. Supervision, J.R.-A., P.N.P. Funding acquisition, J.R.-A., P.N.P., J.K.F. All authors have read and agreed to the published version of the manuscript.

Funding: This research was co-funded by the University of Melbourne and CSIRO through the One Health program (49672540 R43). 
Conflicts of Interest: The authors declare no conflict of interest.

\section{References}

1. Franklinos, L.H.V.; Jones, K.E.; Redding, D.W.; Abubakar, I. The effect of global change on mosquito-borne disease. Lancet Infect. Dis. 2019, 19, e302-e312. [CrossRef]

2. Semenza, J.C.; Suk, J.E. Vector-borne diseases and climate change: A European perspective. FEMS Microbiol. Lett. 2018, 365. [CrossRef]

3. Weaver, S.C.; Reisen, W.K. Present and future arboviral threats. Antivir. Res. 2010, 85, 328-345. [CrossRef] [PubMed]

4. Petersen, L.R.; Powers, A.M. Chikungunya: Epidemiology. F1000Research 2016, 5. [CrossRef]

5. Asad, H.; Carpenter, D.O. Effects of climate change on the spread of zika virus: A public health threat. Rev. Environ. Health 2018, 33, 31-42. [CrossRef]

6. Moureau, G.; Cook, S.; Lemey, P. New insights into flavivirus evolution, taxonomy and biogeographic history, extended by analysis of canonical and alternative coding sequences. PLoS ONE 2015, 10, e0117849. [CrossRef]

7. Ochsenreiter, R.; Hofacker, I.L.; Wolfinger, M.T. Functional RNA structures in the 3'UTR of tick-borne, insect-specific and no-known-vector flaviviruses. Viruses 2019, 11, 298. [CrossRef]

8. Kuno, G.; Chang, G.-J.J.; Tsuchiya, K.R.; Karabatsos, N.; Cropp, C.B. Phylogeny of the Genus Flavivirus. J. Virol. 1998, 72, 73-83. [CrossRef] [PubMed]

9. Mustafa, M.; Rasotgi, V.; Jain, S.; Gupta, V. Discovery of fifth serotype of dengue virus (DENV-5): A new public health dilemma in dengue control. Med. J. Armed Forces India 2015, 71, 67-70. [CrossRef] [PubMed]

10. Waman, V.P.; Kolekar, P.; Ramtirthkar, M.R.; Kale, M.M.; Kulkarni-Kale, U. Analysis of genotype diversity and evolution of Dengue virus serotype 2 using complete genomes. PeerJ 2016, 4, e2326. [CrossRef] [PubMed]

11. Brady, O.J.; Gething, P.W.; Bhatt, S.; Messina, J.P.; Brownstein, J.S.; Hoen, A.G.; Moyes, C.L.; Farlow, A.W.; Scott, T.W.; Hay, S.I. Refining the global spatial limits of Dengue virus transmission by evidence-based consensus. PLoS Negl. Trop. Dis. 2012, 6, e1760. [CrossRef]

12. Zika Virus. 2020. Available online: https://www.who.int/news-room/fact-sheets/detail/zika-virus (accessed on 11 September 2020).

13. Japanese Encephalitis. 2020. Available online: https://www.who.int/news-room/fact-sheets/detail/japaneseencephalitis (accessed on 11 September 2020).

14. Lindquist, L. Recent and historical trends in the epidemiology of Japanese encephalitis and its implication for risk assessment in travellers. J. Travel Med. 2018, 25, 3-9. [CrossRef]

15. Strauss, J.H.; Strauss, E.G. Viruses and Human Disease, 2nd ed.; Elsevier Inc.: Amsterdam, The Netherlands, 2007. [CrossRef]

16. Weaver, S.C.; Lecuit, M. Chikungunya virus and the global spread of a mosquito-borne disease. N. Engl. J. Med. 2015, 372, 1231-1239. [CrossRef]

17. Tsetsarkin, K.; VanLandingham, D.L.; E McGee, C.; Higgs, S. A single mutation in Chikungunya virus affects vector specificity and epidemic potential. PLoS Pathog. 2007, 3, e201. [CrossRef]

18. Schuffenecker, I.; Iteman, I.; Michault, A.; Murri, S.; Frangeul, L.; Vaney, M.-C.; Lavenir, R.; Pardigon, N.; Reynes, J.-M.; Pettinelli, F.; et al. Genome microevolution of Chikungunya viruses causing the Indian Ocean outbreak. PLoS Med. 2006, 3, e263. [CrossRef]

19. Soumahoro, M.-K.; Boelle, P.-Y.; Gaüzère, B.-A.; Atsou, K.; Pelat, C.; Lambert, B.; La Ruche, G.; Gastellu-Etchegorry, M.; Renault, P.; Sarazin, M.; et al. The Chikungunya epidemic on La Réunion Island in 2005-2006: A cost-of-illness study. PLoS Negl. Trop. Dis. 2011, 5, e1197. [CrossRef]

20. Chikungunya. 2020. Available online: https://www.who.int/news-room/fact-sheets/detail/chikungunya (accessed on 11 September 2020).

21. PAHO Chikungunya. 2020. Available online: https://www.paho.org/hq/index.php?option=com_topics\& view $=$ article\&id=343\&Itemid=40931\&lang=en (accessed on 9 April 2020).

22. James, N. Fenner's Veterinary Virology; Elsevier Academic Press: Amsterdam, The Netherlands, 2017. [CrossRef]

23. Kurkela, S.; Manni, T.; Vaheri, A.; Vapalahti, O. Causative agent of Pogosta disease isolated from blood and skin lesions. Emerg. Infect. Dis. 2004, 10, 889-894. [CrossRef] [PubMed] 
24. Lvov, D.K.; Trent, D.W.; Butenko, A.M.; Vladimirtseva, E.A.; Calisher, C.H.; Karabatsos, N. Identity of Karelian fever and Ockelbo viruses determined by serum dilution-plaque reduction neutralization tests and oligonucleotide mapping. Am. J. Trop. Med. Hyg. 1988, 39, 607-610. [CrossRef]

25. Niklasson, B.; Tesh, R.B.J.; Gargan, T.P.; Ennis, W.A.; Espmark, A.; LeDuc, J.W. Association of a Sindbis-like virus with Ockelbo disease in Sweden. Am. J. Trop. Med. Hyg. 1984, 33, 1212-1217. [CrossRef]

26. Liu, X.; Tharmarajah, K.; Taylor, A. Ross River virus disease clinical presentation, pathogenesis and current therapeutic strategies. Microbes Infect. 2017, 19, 496-504. [CrossRef]

27. Aaskov, J.G.; Mataika, J.U.; Lawrence, G.W.; Rabukawaqa, V.; Tucker, M.M.; Miles, J.A.R.; Dalglish, D.A. An epidemic of Ross River virus infection in Fiji, 1979. Am. J. Trop. Med. Hyg. 1981, 30, 1053-1059. [CrossRef] [PubMed]

28. Fauran, P.; Donaldson, M.; Harper, J.; Oseni, R.A.; Aaskov, J.G. Characterization of Ross River viruses isolated from patients with polyarthritis in New Caledonia and Wallis and Futuna Islands. Am. J. Trop. Med. Hyg. 1984, 33, 1228-1231. [CrossRef]

29. Tesh, R.B.; Gajdusek, D.C.; Garruto, R.M.; Cross, J.H.; Rosen, L. The distribution and prevalence of group arbovirus neutralizing antibodies among human populations in Southeast Asia and the Pacific Islands. Am. J. Trop. Med. Hyg. 1975, 24, 664-675. [CrossRef] [PubMed]

30. Vogels, C.B.F.; Rückert, C.; Cavany, S.M.; Perkins, T.A.; Ebel, G.D.; Grubaugh, N.D. Arbovirus coinfection and co-transmission: A neglected public health concern? PLoS Biol. 2019, 17, e3000130. [CrossRef] [PubMed]

31. Yeny Yeny Acosta-Ampudia Center for Autoimmune Diseases Research (CREA), School of Medicine and Health SciencesUniversidad del Rosario 111221 Bogotá Colombia; Pacheco, Y.; Ramírez-Santana, C. Mayaro: An emerging viral threat? Emerg. Microbes Infect. 2018, 7, 1-11. [CrossRef]

32. Gaudreault, N.N.; Madden, D.W.; Wilson, W.C.; Trujillo, J.D.; Richt, J.A. African Swine fever virus: An emerging DNA arbovirus. Front. Veter. Sci. 2020, 7, 215. [CrossRef]

33. Gill, C.M.; Kapadia, R.K.; Beckham, J.D.; Piquet, A.L.; Tyler, K.L.; Pastula, D.M. Usutu virus disease: A potential problem for North America? J. Neurovirol. 2019, 26, 149-154. [CrossRef]

34. Kraemer, M.U.G.; Reiner, R.C.; Brady, O.J.; Messina, J.P.; Gilbert, M.; Pigott, D.M.; Yi, D.; Johnson, K.; Earl, L.; Marczak, L.B.; et al. Past and future spread of the arbovirus vectors Aedes aegypti and Aedes albopictus. Nat. Microbiol. 2019, 4, 854-863. [CrossRef]

35. Öhlund, P.; Lundén, H.; Blomström, A.-L. Insect-specific virus evolution and potential effects on vector competence. Virus Genes 2019, 55, 127-137. [CrossRef]

36. Stollar, V.; Thomas, V.L. An agent in the Aedes aegypti cell line (Peleg) which causes fusion of Aedes albopictus cells. Virology 1975, 64, 367-377. [CrossRef]

37. Sang, R.C.; Gichogo, A.; Gachoya, J.; Dunster, M.D.; Ofula, V.; Hunt, A.R.; Crabtree, M.B.; Miller, B.R.; Dunster, L.M. Isolation of a new flavivirus related to Cell fusing agent virus (CFAV) from field-collected flood-water Aedes mosquitoes sampled from a dambo in central Kenya. Arch. Virol. 2003, 148, 1085-1093. [CrossRef] [PubMed]

38. Hoshino, K.; Isawa, H.; Tsuda, Y.; Yano, K.; Sasaki, T.; Yuda, M.; Takasaki, T.; Kobayashi, M.; Sawabe, K. Genetic characterization of a new insect flavivirus isolated from Culex pipiens mosquito in Japan. Virology 2007, 359, 405-414. [CrossRef]

39. Hoshino, K.; Isawa, H.; Tsuda, Y.; Sawabe, K.; Kobayashi, M. Isolation and characterization of a new insect flavivirus from Aedes albopictus and Aedes flavopictus mosquitoes in Japan. Virology 2009, 391, 119-129. [CrossRef]

40. Roiz, D.; Vázquez, A.; Rosso, F.; Arnoldi, D.; Girardi, M.; Cuevas, L.; Perez-Pastrana, E.; Seco, M.P.S.; Tenorio, A.; Rizzoli, A. Detection of a new insect flavivirus and isolation of Aedes flavivirus in Northern Italy. Parasites Vectors 2012, 5, 223. [CrossRef]

41. Haddow, A.D.; Guzman, H.; Popov, V.L.; Wood, T.G.; Widen, S.G.; Haddow, A.D.; Tesh, R.B.; Weaver, S.C. First isolation of Aedes flavivirus in the Western Hemisphere and evidence of vertical transmission in the mosquito Aedes (Stegomyia) albopictus (Diptera: Culicidae). Virology 2013, 440, 134-139. [CrossRef] [PubMed]

42. Cook, S.; Moureau, G.; Harbach, R.E.; Mukwaya, L.; Goodger, K.; Ssenfuka, F.; Gould, E.; Holmes, E.C.; De Lamballerie, $X$. Isolation of a novel species of flavivirus and a new strain of Culex flavivirus (Flaviviridae) from a natural mosquito population in Uganda. J. Gen. Virol. 2009, 90, 2669-2678. [CrossRef] 
43. Bolling, B.G.; Olea-Popelka, F.J.; Eisen, L.; Moore, C.G.; Blair, C.D. Transmission dynamics of an insect-specific flavivirus in a naturally infected Culex pipiens laboratory colony and effects of co-infection on vector competence for West Nile virus. Virology 2012, 427, 90-97. [CrossRef]

44. Crabtree, M.; Nga, P.T.; Miller, B.R. Isolation and characterization of a new mosquito flavivirus, Quang Binh virus, from Vietnam. Arch. Virol. 2009, 154, 857-860. [CrossRef]

45. Huhtamo, E.; Moureau, G.; Cook, S.; Julkunen, O.; Putkuri, N.; Kurkela, S.; Uzcátegui, N.Y.; Harbach, R.E.; Gould, E.A.; Vapalahti, O.; et al. Novel insect-specific flavivirus isolated from northern Europe. Virology 2012, 433, 471-478. [CrossRef] [PubMed]

46. Hobson-Peters, J.; Yam, A.W.Y.; Lu, J.W.F.; Setoh, Y.X.; May, F.J.; Kurucz, N.; Walsh, S.; Prow, N.A.; Davis, S.S.; Weir, R.; et al. A new insect-specific Flavivirus from Northern Australia suppresses replication of West Nile Virus and Murray Valley encephalitis virus in co-infected mosquito cells. PLoS ONE 2013, 8, e56534. [CrossRef]

47. Blitvich, B.J.; Firth, A.E. Insect-specific Flaviviruses: A systematic review of their discovery, host range, mode of transmission, superinfection exclusion potential and genomic organization. Viruses 2015, 7, 1927-1959. [CrossRef]

48. Pybus, O.G.; Rambaut, A.; Holmes, E.C.; Harvey, P.H. New inferences from tree shape: Numbers of missing taxa and population growth rates. Syst. Biol. 2002, 51, 881-888. [CrossRef]

49. Hermanns, K.; Zirkel, F.; Kopp, A.; Marklewitz, M.; Rwego, I.B.; Estrada, A.; Gillespie, T.R.; Drosten, C.; Junglen, S. Discovery of a novel alphavirus related to Eilat virus. J. Gen. Virol. 2017, 98, 43-49. [CrossRef]

50. Torii, S.; Orba, Y.; Hang'Ombe, B.M.; Mweene, A.S.; Wada, Y.; Anindita, P.D.; Phongphaew, W.; Qiu, Y.; Kajihara, M.; Mori-Kajihara, A.; et al. Discovery of Mwinilunga alphavirus: A novel alphavirus in Culex mosquitoes in Zambia. Virus Res. 2018, 250, 31-36. [CrossRef]

51. Batovska, J.; Buchmann, J.P.; Holmes, E.C.; Lynch, S.E. Coding-complete genome sequence of Yada Yada virus, a novel Alphavirus detected in Australian mosquitoes. Microbiol. Resour. Announc. 2020, 9. [CrossRef]

52. Nasar, F.; Palacios, G.; Gorchakov, R.V.; Guzman, H.; Da Rosa, A.P.T.; Savji, N.; Popov, V.L.; Sherman, M.B.; Lipkin, W.I.; Tesh, R.B.; et al. Eilat virus, a unique Alphavirus with host range restricted to insects by RNA replication. Proc. Natl. Acad. Sci. USA 2012, 109, 14622-14627.

53. Hermanns, K.; Marklewitz, M.; Zirkel, F.; Overheul, G.J.; Page, R.A.; Loaiza, J.R.; Drosten, C.; Van Rij, R.P.; Junglen, S. Agua Salud alphavirus defines a novel lineage of insect-specific alphaviruses discovered in the New World. J. Gen. Virol. 2020, 101, 96-104. [CrossRef]

54. Samina, I.; Margalit, J.; Peleg, J. Isolation of viruses from mosquitoes of the Negev, Israel. Trans. R. Soc. Trop. Med. Hyg. 1986, 80, 471-472. [CrossRef]

55. Nasar, F.; Haddow, A.D.; Tesh, R.B.; Weaver, S.C. Eilat virus displays a narrow mosquito vector range. Parasites Vectors 2014, 7, 1-10. [CrossRef]

56. Ren, X.; Rasgon, J.L. Potential for the Anopheles gambiae Densonucleosis virus to act as an "Evolution-Proof" biopesticide. J. Virol. 2010, 84, 7726-7729. [CrossRef]

57. Johnson, R.M.; Rasgon, J.L. Densonucleosis viruses ('densoviruses') for mosquito and pathogen control. Curr. Opin. Insect Sci. 2018, 28, 90-97. [CrossRef] [PubMed]

58. Agboli, E.; Leggewie, M.; Altinli, M.; Schnettler, E. Mosquito-specific viruses-Transmission and interaction. Viruses 2019, 11, 873. [CrossRef]

59. Kean, J.; Rainey, S.M.; McFarlane, M.; Donald, C.L.; Schnettler, E.; Kohl, A.; Pondeville, E. Fighting Arbovirus transmission: Natural and engineered control of vector competence in Aedes mosquitoes. Insects 2015, 6, 236-278. [CrossRef]

60. Johnson, K.N. The impact of Wolbachia on virus infection in mosquitoes. Viruses 2015, 7, 5705-5717. [CrossRef]

61. Walker, T.G.; Johnson, P.H.; Moreira, L.A.; Iturbeormaetxe, I.; Frentiu, F.D.; McMeniman, C.J.; Leong, Y.S.; Dong, Y.; Axford, J.K.; Kriesner, P.; et al. The wMel Wolbachia strain blocks dengue and invades caged Aedes aegypti populations. Nat. Cell Biol. 2011, 476, 450-453. [CrossRef]

62. Landmann, F. The Wolbachia Endosymbionts. Bact. Intracell. 2019, 7, 139-153. [CrossRef]

63. Mousson, L.; Martin, E.; Zouache, K.; Madec, Y.; Mavingui, P.; Failloux, A.B. Wolbachiamodulates Chikungunya replication inAedes albopictus. Mol. Ecol. 2010, 19, 1953-1964. [CrossRef]

64. Mousson, L.; Zouache, K.; Arias-Goeta, C.; Raquin, V.; Mavingui, P.; Failloux, A.-B. The native Wolbachia symbionts limit transmission of Dengue virus in Aedes albopictus. PLoS Negl. Trop. Dis. 2012, 6, e1989. [CrossRef] 
65. Frentiu, F.D.; Zakir, T.; Walker, T.; Popovici, J.; Pyke, A.T.; Hurk, A.V.D.; McGraw, E.A.; O’Neill, S.L. Limited Dengue virus replication in field-collected Aedes aegypti mosquitoes infected with Wolbachia. PLoS Negl. Trop. Dis. 2014, 8, e2688. [CrossRef]

66. Nazni, W.A.; Hoffmann, A.A.; NoorAfizah, A.; Cheong, Y.L.; Mancini, M.V.; Golding, N.; Kamarul, G.M.R.; Arif, M.A.K.; Thohir, H.; NurSyamimi, H.; et al. Establishment of Wolbachia strain wAlbB in Malaysian populations of Aedes aegypti for Dengue control. Curr. Biol. 2019, 29, 4241-4248.e5. [CrossRef]

67. Xue, L.; Fang, X.; Hyman, J.M. Comparing the effectiveness of different strains of Wolbachia for controlling chikungunya, dengue fever and zika. PLoS Negl. Trop. Dis. 2018, 12, e0006666. [CrossRef]

68. Tan, C.H.; Wong, P.J.; Li, M.I.; Yang, H.; Ng, L.-C.; O’Neill, S.L. wMel limits zika and chikungunya virus infection in a Singapore Wolbachia-introgressed Ae. aegypti strain, wMel-Sg. PLoS Negl. Trop. Dis. 2017, 11, e0005496. [CrossRef]

69. Hurk, A.F.V.D.; Hall-Mendelin, S.; Pyke, A.T.; Frentiu, F.D.; McElroy, K.; Day, A.; Higgs, S.; O’Neill, S.L. Impact of Wolbachia on infection with Chikungunya and Yellow fever viruses in the mosquito vector Aedes aegypti. PLoS Negl. Trop. Dis. 2012, 6, e1892. [CrossRef]

70. Ford, S.A.; Allen, S.L.; Ohm, J.R.; Sigle, L.T.; Sebastian, A.; Albert, I.; Chenoweth, S.F.; McGraw, E.A. Selection on Aedes aegypti alters Wolbachia-mediated dengue virus blocking and fitness. Nat. Microbiol. 2019, 4, 1832-1839. [CrossRef] [PubMed]

71. O'Reilly, K.M.; Hendrickx, E.; Kharisma, D.D.; Wilastonegoro, N.N.; Carrington, L.B.; Elyazar, I.R.F.; Kucharski, A.J.; Lowe, R.; Flasche, S.; Pigott, D.M.; et al. Estimating the burden of dengue and the impact of release of wMel Wolbachia-infected mosquitoes in Indonesia: A modelling study. BMC Med. 2019, 17, 1-14. [CrossRef] [PubMed]

72. Aliota, M.T.; Walker, E.C.; Yepes, A.U.; Velez, I.D.; Christensen, B.M.; Osorio, J.E. The wMel Strain of Wolbachia Reduces Transmission of Chikungunya Virus in Aedes aegypti. PLoS Negl. Trop. Dis. 2016, 10, e0004677. [CrossRef]

73. Indriani, C.; Tantowijoyo, W.; Rancès, E.; Andari, B.; Prabowo, E.; Yusdi, D.; Ansari, M.R.; Wardana, D.S.; Supriyati, E.; Nurhayati, I.; et al. Reduced dengue incidence following deployments of Wolbachia-infected Aedes aegypti in Yogyakarta, Indonesia: A quasi-experimental trial using controlled interrupted time series analysis. Gates Open Res. 2020, 4, 50. [CrossRef]

74. Zélé, F.; Nicot, A.; Berthomieu, A.; Weill, M.; Duron, O.; Rivero, A. Wolbachia increases susceptibility to Plasmodium infection in a natural system. Proc. R. Soc. B Biol. Sci. 2014, 281, 20132837. [CrossRef]

75. Alphey, L.; McKemey, A.; Nimmo, D.; Oviedo, M.N.; Lacroix, R.; Matzen, K.; Beech, C. Genetic control of Aedes mosquitoes. Pathog. Glob. Health 2013, 107, 170-179. [CrossRef] [PubMed]

76. Gutierrez, A.P.; Ponti, L.; Arias, P.A. Deconstructing the eradication of new world screwworm in North America: Retrospective analysis and climate warming effects. Med Veter. Entomol. 2019, 33, 282-295. [CrossRef]

77. Robinson, A.S. Genetic basis of the sterile insect technique. In Sterile Insect Technique: Principles and Practice in Area-Wide Integrated Pest. Management; Springer: Dordrecht, The Netherlands, 2005; pp. 95-114. [CrossRef]

78. Buchman, A.; Gamez, S.; Li, M.; Antoshechkin, I.; Li, H.-H.; Wang, H.-W.; Chen, C.-H.; Klein, M.J.; Duchemin, J.-B.; Crowe, J.E.; et al. Broad dengue neutralization in mosquitoes expressing an engineered antibody. PLoS Pathog. 2020, 16, e1008103. [CrossRef]

79. Lambrechts, L.; Saleh, M.-C. Manipulating mosquito tolerance for Arbovirus control. Cell Host Microbe 2019, 26, 309-313. [CrossRef]

80. Kistler, K.E.; Vosshall, L.B.; Matthews, B.J. Genome Engineering with CRISPR-Cas9 in the Mosquito Aedes aegypti. Cell Rep. 2015, 11, 51-60. [CrossRef]

81. Evans, B.R.; Kotsakiozi, P.; Costa-Da-Silva, A.L.; Ioshino, R.S.; Garziera, L.; Pedrosa, M.C.; Malavasi, A.; Virginio, J.F.; Capurro, M.L.; Powell, J.R. Transgenic Aedes aegypti mosquitoes transfer genes into a natural population. Sci. Rep. 2019, 9, 1-6. [CrossRef]

82. Oxitec Transitioning FriendlyTM Self-limiting Mosquitoes to 2nd Generation Technology Platform, Paving Way to New Scalability, Performance and Cost Breakthroughs. 2020. Available online: https://www.oxitec.com/en/news/oxitec-transitioning-friendly-self-limiting-mosquitoes-to-2ndgeneration-technology-platform-paving-way-to-new-scalability-performance-and-cost-breakthroughs (accessed on 21 September 2020). 
83. Florida is about to Release 750 Million Genetically Modified Mosquitoes-Here's Why-Mirror Online. Available online: https://www.mirror.co.uk/science/florida-release-750-million-genetically-22556042 (accessed on 21 September 2020).

84. Meghani, Z.; Boëte, C. Genetically engineered mosquitoes, Zika and other arboviruses, community engagement, costs and patents: Ethical issues. PLoS Negl. Trop. Dis. 2018, 12, e0006501. [CrossRef] [PubMed]

85. McKinney, H.H. Virus mixtures that may not be detected in young tobacco plants. Phytopathology 1926, 16, 79.

86. Bergua, M.; Kang, S.-H.; Folimonova, S.Y. Understanding superinfection exclusion by complex populations of Citrus tristeza virus. Virology 2016, 499, 331-339. [CrossRef] [PubMed]

87. Folimonova, S.Y.; Robertson, C.J.; Shilts, T.; Folimonov, A.S.; Hilf, M.E.; Garnsey, S.M.; Dawson, W.O. Infection with strains of citrus Tristeza virus does not exclude superinfection by other strains of the virus. J. Virol. 2009, 84, 1314-1325. [CrossRef] [PubMed]

88. Ziebell, H.; Carr, J.P. Cross-protection. Int. Rev. Cytol. 2010, 76, 211-264. [CrossRef]

89. Boller, T.; He, S.Y. Innate immunity in plants: An arms race between pattern recognition receptors in plants and effectors in microbial pathogens. Science 2009, 324, 742-744. [CrossRef]

90. Voinnet, O. Induction and suppression of RNA silencing: Insights from viral infections. Nat. Rev. Genet. 2005, 6, 206-220. [CrossRef]

91. Guo, Q.; Liu, Q.; Smith, N.A.; Liang, G.; Wang, M.-B. RNA silencing in plants: Mechanisms, technologies and applications in horticultural crops. Curr. Genom. 2016, 17, 476-489. [CrossRef]

92. Johnston, R.E.; Wan, K.; Bose, H.R. Homologous interference induced by Sindbis virus. J. Virol. 1974, 14, 1076-1082. [CrossRef] [PubMed]

93. Whitaker-Dowling, P.; Ungner, J.S.; Widnell, C.C.; Wilcox, D.K. Superinfect on exclusion by vesicular stomatitis virus. Virology 1983, 131, 137-143. [CrossRef]

94. Claus, C.; Tzeng, W.-P.; Liebert, U.G.; Frey, T.K. Rubella virus-induced superinfection exclusion studied in cells with persisting replicons. J. Gen. Virol. 2007, 88, 2769-2773. [CrossRef]

95. Huang, Y.; Dai, H.; Ke, R. Principles of effective and robust innate immune response to viral infections: A multiplex network analysis. Front. Immunol. 2019, 10. [CrossRef]

96. Laurie, K.L.; Horman, W.; A Carolan, L.; Chan, K.F.; Layton, D.; Bean, A.; Vijaykrishna, D.; Reading, P.C.; McCaw, J.M.; Barr, I.G. Evidence for viral interference and cross-reactive protective immunity between influenza B virus lineages. J. Infect. Dis. 2018, 217, 548-559. [CrossRef]

97. Polacino, P.; Kaplan, G.; Palma, E.L. Homologous interference by a foot-and-mouth disease virus strain attenuated for cattle. Arch. Virol. 1985, 86, 291-301. [CrossRef] [PubMed]

98. Criddle, A.; Thornburg, T.; Kochetkova, I.; DePartee, M.; Taylor, M.P. gD-Independent Superinfection Exclusion of Alphaherpesviruses. J. Virol. 2016, 90, 4049-4058. [CrossRef]

99. Abrao, E.P.; Da Fonseca, B.A.L. Infection of mosquito cells (C6/36) by Dengue-2 virus interferes with subsequent infection by Yellow fever virus. Vector Borne Zoonotic Dis. 2016, 16, 124-130. [CrossRef]

100. Stollar, V.; Shenk, T.E. Homologous viral interference in Aedes albopictus cultures chronically infected with Sindbis virus. J. Virol. 1973, 11, 592-595. [CrossRef] [PubMed]

101. Eaton, B.T. Heterologous interference in Aedes albopictus cells infected with alphaviruses. J. Virol. 1979, 30, 45-55. [CrossRef]

102. Karpf, A.R.; Lenches, E.; Strauss, E.G.; Strauss, J.H.; Brown, D.T. Superinfection exclusion of alphaviruses in three mosquito cell lines persistently infected with Sindbis virus. J. Virol. 1997, 71, 7119-7123. [CrossRef]

103. Vazeille, M.; Mousson, L.; Martin, E.; Failloux, A.-B. Orally co-infected Aedes albopictus from La Reunion Island, Indian Ocean, can deliver both Dengue and Chikungunya infectious viral particles in their saliva. PLoS Negl. Trop. Dis. 2010, 4, e706. [CrossRef]

104. Göertz, G.P.; Vogels, C.B.F.; Geertsema, C.; Koenraadt, C.J.M.; Pijlman, G.P. Mosquito co-infection with Zika and chikungunya virus allows simultaneous transmission without affecting vector competence of Aedes aegypti. PLoS Negl. Trop. Dis. 2017, 11, e0005654. [CrossRef]

105. Furuya-Kanamori, L.; Liang, S.; Milinovich, G.; Magalhaes, R.J.S.; Clements, A.C.A.; Hu, W.; Brasil, P.; Frentiu, F.D.; Dunning, R.; Yakob, L. Co-distribution and co-infection of chikungunya and dengue viruses. BMC Infect. Dis. 2016, 16, 1-11. [CrossRef] [PubMed]

106. Beaty, B.J.; Bishop, D.H.; Gay, M.; Fuller, F. Interference between bunyaviruses in Aedes triseriatus mosquitoes. Virology 1983, 127, 83-90. [CrossRef] 
107. Kenney, J.L.; Solberg, O.D.; Langevin, S.A.; Brault, A.C. Characterization of a novel insect-specific flavivirus from Brazil: Potential for inhibition of infection of arthropod cells with medically important flaviviruses. J. Gen. Virol. 2014, 95, 2796-2808. [CrossRef]

108. Nasar, F.; Erasmus, J.H.; Haddow, A.D.; Tesh, R.B.; Weaver, S.C. Eilat virus induces both homologous and heterologous interference. Virology 2015, 484, 51-58. [CrossRef]

109. Goenaga, S.; Kenney, J.L.; Duggal, N.K.; DeLorey, M.; Ebel, G.D.; Zhang, B.; Levis, S.C.; Enria, D.A.; Brault, A.C. Potential for co-infection of a mosquito-specific Flavivirus, Nhumirim Virus, to block West Nile virus transmission in mosquitoes. Viruses 2015, 7, 5801-5812. [CrossRef]

110. Romo, H.; Kenney, J.L.; Blitvich, B.J.; Brault, A.C. Restriction of Zika virus infection and transmission in Aedes aegypti mediated by an insect-specific flavivirus. Emerg. Microbes Infect. 2018, 7. [CrossRef] [PubMed]

111. Folimonova, S.Y. Superinfection exclusion is an active virus-controlled function that requires a specific viral protein. J. Virol. 2012, 86, 5554-5561. [CrossRef]

112. Pepin, K.M.; Lambeth, K.; Hanley, K.A. Asymmetric competitive suppression between strains of dengue virus. BMC Microbiol. 2008, 8, 28. [CrossRef]

113. Fujita, R.; Kato, F.; Kobayashi, D.; Murota, K.; Takasaki, T.; Tajima, S.; Lim, C.-K.; Saijo, M.; Isawa, H.; Sawabe, K. Persistent viruses in mosquito cultured cell line suppress multiplication of flaviviruses. Heliyon 2018, 4, e00736. [CrossRef]

114. Amoa-Bosompem, M.; Kobayashi, D.; Murota, K.; Faizah, A.N.; Itokawa, K.; Fujita, R.; Osei, J.H.N.; Agbosu, E.; Pratt, D.; Kimura, S.; et al. Entomological assessment of the status and risk of mosquito-borne Arboviral transmission in Ghana. Viruses 2020, 12, 147. [CrossRef]

115. Baluda, M.A. Loss of viral receptors in homologous interference by ultraviolet-irradiated Newcastle disease virus. Virology 1959, 7, 315-327. [CrossRef]

116. Steck, F.T.; Rubin, H. The mechanism of interference between an avian leukosis virus and rous sarcoma virus. Virology 1966, 29, 628-641. [CrossRef]

117. Lee, Y.-M.; Tscherne, D.M.; Yun, S.-I.; Frolov, I.; Rice, C.M. Dual Mechanisms of pestiviral superinfection exclusion at entry and RNA replication. J. Virol. 2005, 79, 3231-3242. [CrossRef]

118. Adams, R.H.; Brown, D.T. BHK cells expressing Sindbis virus-induced homologous interference allow the translation of nonstructural genes of superinfecting virus. J. Virol. 1985, 54, 351-357. [CrossRef]

119. Singh, I.R.; Suomalainen, M.; Varadarajan, S.; Garoff, H.; Helenius, A. Multiple mechanisms for the inhibition of entry and uncoating of superinfecting Semliki Forest virus. Virology 1997, 231, 59-71. [CrossRef]

120. Singh, I.; Helenius, A. Role of ribosomes in Semliki Forest virus nucleocapsid uncoating. J. Virol. 1992, 66, 7049-7058. [CrossRef] [PubMed]

121. Wengler, G. The mode of assembly of alphavirus cores implies a mechanism for the disassembly of the cores in the early stages of infection. Arch. Virol. 1987, 94, 1-14. [CrossRef]

122. Rupp, J.C.; Sokoloski, K.J.; Gebhart, N.N.; Hardy, R.W. Alphavirus RNA synthesis and non-structural protein functions. J. Gen. Virol. 2015, 96, 2483-2500. [CrossRef] [PubMed]

123. Shirako, Y.; Strauss, J.H. Regulation of Sindbis virus RNA replication: Uncleaved P123 and nsP4 function in minus-strand RNA synthesis, whereas cleaved products from P123 are required for efficient plus-strand RNA synthesis. J. Virol. 1994, 68, 1874-1885. [CrossRef] [PubMed]

124. Lemm, J.; Rice, C.M. Assembly of functional Sindbis virus RNA replication complexes: Requirement for coexpression of P123 and P34. J. Virol. 1993, 67, 1905-1915. [CrossRef]

125. Kiiver, K.; Tagen, I.; Žusinaite, E.; Tamberg, N.; Fazakerley, J.K.; Merits, A. Properties of non-structural protein 1 of Semliki Forest virus and its interference with virus replication. J. Gen. Virol. 2008, 89, 1457-1466. [CrossRef]

126. Das, P.K.; Merits, A.; Lulla, A. Functional cross-talk between distant domains of Chikungunya virus non-structural protein 2 is decisive for its RNA-modulating activity. J. Biol. Chem. 2014, 289, 5635-5653. [CrossRef]

127. Zou, G.; Puig-Basagoiti, F.; Zhang, B.; Qing, M.; Chen, L.; Pankiewicz, K.W.; Felczak, K.; Yuan, Z.; Shi, P.-Y. A single-amino acid substitution in West Nile virus $2 \mathrm{~K}$ peptide between NS4A and NS4B confers resistance to lycorine, a flavivirus inhibitor. Virology 2009, 384, 242-252. [CrossRef]

128. Varjak, M.; Leggewie, M.; Schnettler, E. The antiviral piRNA response in mosquitoes? J. Gen. Virol. 2018, 99, 1551-1562. [CrossRef] 
129. Brackney, D.E.; Scott, J.C.; Sagawa, F.; Woodward, J.E.; Miller, N.A.; Schilkey, F.D.; Mudge, J.; Wilusz, J.; Olson, K.E.; Blair, C.D.; et al. C6/36 Aedes albopictus cells have a dysfunctional antiviral RNA interference response. PLoS Negl. Trop. Dis. 2010, 4, e856. [CrossRef]

130. Léger, P.; Lara, E.; Jagla, B.; Sismeiro, O.; Mansuroglu, Z.; Coppée, J.Y.; Bonnefoy, E.; Bouloy, M. Dicer-2and Piwi-mediated RNA interference in Rift Valley Fever virus-infected mosquito cells. J. Virol. 2012, 87, 1631-1648. [CrossRef] [PubMed]

131. Snyder, J.E.; Kulcsar, K.A.; Schultz, K.L.W.; Riley, C.P.; Neary, J.T.; Marr, S.; Jose, J.; Griffin, D.E.; Kuhn, R.J. Functional characterization of the Alphavirus TF protein. J. Virol. 2013, 87, 8511-8523. [CrossRef]

132. Lee, S.; E Owen, K.; Choi, H.-K.; Lee, H.; Lu, G.; Wengler, G.; Brown, D.T.; Rossmann, M.G.; Kuhn, R.J. Identification of a protein binding site on the surface of the alphavirus nucleocapsid and its implication in virus assembly. Structure 1996, 4, 531-541. [CrossRef]

133. Metz, S.W.; Geertsema, C.; E Martina, B.; Andrade, P.; Heldens, J.G.; Van Oers, M.M.; Goldbach, R.W.; Vlak, J.M.; Pijlman, G.P. Functional processing and secretion of Chikungunya virus E1 and E2 glycoproteins in insect cells. Virol. J. 2011, 8, 353. [CrossRef]

134. Gaedigk-Nitschko, K.; Ding, M.; Levy, M.A.; Schlesinger, M.J. Site-directed mutations in the sindbis virus 6K protein reveal sites for fatty acylation and the underacylated protein affects virus release and virion structure. Virology 1990, 175, 282-291. [CrossRef]

135. Jose, J.; E Snyder, J.; Kuhn, R.J. A structural and functional perspective of alphavirus replication and assembly. Futur. Microbiol. 2009, 4, 837-856. [CrossRef] [PubMed]

136. Zou, G.; Zhang, B.; Lim, P.-Y.; Yuan, Z.; Bernard, K.A.; Shi, P.-Y. Exclusion of West Nile virus superinfection through RNA replication. J. Virol. 2009, 83, 11765-11776. [CrossRef] [PubMed]

137. Harada, T.; Tautz, N.; Thiel, H.-J. E2-p7 Region of the bovine viral Diarrhea virus polyprotein: Processing and functional studies. J. Virol. 2000, 74, 9498-9506. [CrossRef]

138. Rückert, C.; Weger-Lucarelli, J.; Garcia-Luna, S.M.; Young, M.C.; Byas, A.D.; Murrieta, R.A.; Fauver, J.R.; Ebel, G.D. Impact of simultaneous exposure to arboviruses on infection and transmission by Aedes aegypti mosquitoes. Nat. Commun. 2017, 8, 15412. [CrossRef]

139. Chaves, B.A.; Orfano, A.S.; Nogueira, P.M.; Rodrigues, N.B.; Campolina, T.B.; Nacif-Pimenta, R.; Pires, A.C.A.M.; Júnior, A.B.V.; Paz, A.D.C.; Vaz, E.B.D.C.; et al. Coinfection with Zika virus (ZIKV) and Dengue virus results in preferential ZIKV transmission by vector bite to vertebrate host. J. Infect. Dis. 2018, 218, 563-571. [CrossRef]

140. Cross, S.T.; Kapuscinski, M.L.; Perino, J.; Maertens, B.L.; Weger-Lucarelli, J.; Ebel, G.D.; Stenglein, M.D. Co-Infection patterns in individual ixodes scapularis ticks reveal associations between viral, eukaryotic and bacterial microorganisms. Viruses 2018, 10, 388. [CrossRef]

141. Muturi, E.J.; Buckner, E.; Bara, J. Superinfection interference between dengue-2 and dengue-4 viruses inAedes aegyptimosquitoes. Trop. Med. Int. Health 2017, 22, 399-406. [CrossRef] [PubMed]

142. Hunter, C.; Winston, W.; Molodowitch, C.; Feinberg, E.; Shih, J.D.; Sutherlin, M.; Wright, A.; Fitzgerald, M. Systemic RNAi in Caenorhabditis elegans. In Cold Spring Harbor Symposia on Quantitative Biology; Cold Spring Harbor Laboratory Press: Cold Spring Harbor, NY, USA, 2006; Volume 71, pp. 95-100. [CrossRef]

143. Lee, W.-S.; Webster, J.A.; Madzokere, E.T.; Stephenson, E.B.; Herrero, L.J. Mosquito antiviral defense mechanisms: A delicate balance between innate immunity and persistent viral infection. Parasites Vectors 2019, 12, 1-12. [CrossRef]

144. Kingsolver, M.B.; Huang, Z.; Hardy, R.W. Insect antiviral innate immunity: Pathways, effectors, and connections. J. Mol. Biol. 2013, 425, 4921-4936. [CrossRef]

Publisher's Note: MDPI stays neutral with regard to jurisdictional claims in published maps and institutional affiliations.

(C) 2020 by the authors. Licensee MDPI, Basel, Switzerland. This article is an open access article distributed under the terms and conditions of the Creative Commons Attribution (CC BY) license (http://creativecommons.org/licenses/by/4.0/). 